\title{
Rekreasyonda Algılanan Sağlık Çıktıları Ölçeğinin Türkçe Versiyonunun Psikometrik Özellikleri
}

\section{Psychometric Properties of Perceived Health Outcomes of Recreation Scale-Turkish Version}

\author{
${ }^{1}$ Tennur YERLISU LAPA \\ ${ }^{2}$ Emrah SERDAR \\ ${ }^{1}$ Evren TERCAN KAAS \\ ${ }^{3}$ Veli Ozan ÇAKIR \\ ${ }^{1}$ Elif KÖSE
}

\author{
${ }^{1}$ Akdeniz Üniversitesi \\ 2 İstanbul Üniversitesi-Cerrahpaşa \\ ${ }^{3}$ Alanya Alaaddin Keykubat \\ Üniversitesi
}

\section{Yazıșma Adresi \\ Corresponding Address: \\ Doç. Dr. Tennur YERLİSU LAPA}

ORCID: 0000-0002-8647-1473

Akdeniz Üniversitesi Spor Bilimleri Fakültesi

E-posta: tennur@akdeniz.edu.tr
Gelis Tarihi (Received): 03.02.2020

Kabul Tarihi (Accepted): 22.06.2020

\section{öz}

Bu çalışmanın amacı Rekreasyonda Algılanan Sağlık Çıktıları Ölçeğinin (RASÇÖ) geçerlik ve güvenirlik değerlerinin incelenmesidir. Araştırma örneklemini oluşturan ilk grup; bir platformun düzenli olarak organize ettiği açık hava rekreasyon etkinliğine katılan ve düzenli olarak haftada en az iki kez koşan 166 kadın ve 179 erkek olmak üzere toplam 345 katılımcıdan (kadınyaş ort $=31.59 \pm 9.36$, erkekyaş ort $=34.36 \pm 11.10$, toplamyaş ort $=33.02 \pm 10.38$ yıl), ikinci grup ise 91 kadın ve 109 erkek olmak üzere toplam 200 katılımcıdan (kadınyaş ort $=33.24 \pm 8.71$, erkekyaş ort $=33.18 \pm 9.03$, toplamyaş ort=33.21 \pm 8.87 yıl) oluşmaktadır. Ölçeğin dil geçerliliği süreçlerinden sonra RASçÖ’nün yapı geçerliğini sınamak amacıyla birinci grupta uygulanan açımlayıcı faktör analiz sonuçları; yapının üç faktörlü olduğunu ortaya koymaktadır. Buna göre birinci faktör toplam varyansın \%25.98'ini; ikinci faktör toplam varyansın \%22.30'unu ve üçüncü faktör toplam varyansın \%18.05'ini açıklamakta ve toplam varyansın \%66.34'ünü açıkladığı saptanmıştır. RASÇÖ’nün üç faktörlü yapısının düzenli egzersiz yapan bireyler üzerinde doğrulanıp doğrulanmadığını ortaya koymak için yapılan Doğrulayıcı Faktör analizi sonuçları ise yapıyı desteklemektedir. Birinci düzey DFA analizi, RASÇÖ’nün orijinal formundaki gibi üç faktörlü yapısını doğrulamış ve Türkçe uyarlaması yapılan ölçek maddelerinin orijinal formdaki maddeler ile örtüştüğü tespit edilmiştir. Birinci ve ikinci düzey DFA analizi sonuçlarından elde edilen uyum indekslerinin hem kabul edilebilir ve mükemmel uyum indeksleri arasında yer aldığı hem de birbirine yakın olduğu saptanmıştır ve uyum yeterliğinin iyi olduğu tespit edilmiştir. Ölçeğin üç alt boyutu için hesaplanan Cronbach alfa ve bileşik güvenirlik katsayıları ölçeğin güvenilir olduğunu ortaya koymaktadır. Sonuç olarak; RASÇÖ Türkçe versiyonunun geçerli ve güvenilir bir ölçüm aracı olarak serbest zaman ve rekreasyon araştırmalarında kullanılabileceği söylenebilir.

Anahtar Kelimeler: Algılanan sağlık çıktıları, Yapı geçerliği, Güvenirlik

\section{ABSTRACT}

The aim of this study is to assess the validity and reliability of the Turkish version of "The Perceived Health Outcomes of Recreation Scale (PHORS)" which was developed by Gómez et al. (2016). The sample of this study consisted of two groups who attended an outdoor recreational organization in which members regularly run at least twice a week. The first group included 345 participants ( 166 females and 179 males, femaleage mean $=31.59 \pm 9.36$, maleage mean $=34.36 \pm 11.10$, totalage mean $=33.02 \pm 10.38$ ) and the second group consisted of 200 participants ( 91 females and 109 males, femaleage mean=33.24 \pm 8.71 , maleage mean $=33.18 \pm 9.03$, totalage mean=33.21 \pm 8.87 ). After the language validity processes of the scale according to the results of Exploratory Factor Analysis (EFA) applied to the first group to test construct validity of PHORS, three factors were determined and showed that it explained $66.34 \%$ of the total variance. The first factor explained $25.98 \%$, the second one explained $22.30 \%$ and the third one explained $18.05 \%$ of the total variance. Confirmatory Factor Analysis (CFA), conducted to test three factors construct of PHORS with participants doing regular exercises, supported the results. The results of the first stage CFA confirmed the three factors construct of PHORS as in the original form and suggested that Turkish adaptation of items had similar features with the original items. Fit indices obtained from the results of the first and second stage CFA were determined both between acceptable and perfect values and close to each other. Cronbach's Alpha and composite reliability coefficients calculated for three subscales of PHORS indicated that the scale is reliable. As a result, the Turkish version of PHORS is a reliable and valid assessment tool which can be used in leisure and recreation research.

Key Words: Perceived health outcomes, Construct validity, Reliability 


\section{GíRIŞ}

Serbest zaman literatüründe rekreasyon faaliyetlerine katılımın fiziksel ve ruhsal faydalarını inceleyen çeşitli çalışmalar bulunmaktadır (Chang ve diğ., 2018). Serbest zaman faaliyetlerine katılım sırasında elde edilen olumlu etkiler, Driver ve diğ. (1991) tarafından serbest zaman faydası olarak adlandırılmaktadır. Bu kavram Driver (1998) ve Moore ve Driver (2005) tarafindan üç başlık altında sınıflandırılmış, bunlar sırasıyla önceki durumda daha istenilen bir durumda olma haline yol açan iyileştirilmiş durum, istenilen bir durumun korunarak istenmeyen daha kötü bir durumun önlenmesi ve tatmin edici bir rekreasyon deneyiminin gerçekleştirilmesi şeklinde ifade edilmiştir.

Ho (2008) tarafından geliştirilen ve Akgül ve diğ., (2018) tarafından dilimize adapte edilen bir ölçekte ise serbest zaman faydaları fiziksel, psikolojik, sosyal faydalar alt boyutları yapıyı tanımlamaktadır. Serbest zaman faydalarının öncülerinden olan ve 1975 yılında yaptıkları çalışmayla bu konuyu ele alan Driver ve Brown, modellerini kurgularken bireyin güdüleri, beklenti ve geçmiş tecrübelerini ele alarak kendisiyle başlamış ve çıktı olarak bu katılımın bir dizi tecrübesine yer vermiştir (Brown, 2016). Driver'nn serbest zamanla ilgili olarak iyileştirilmiş durum, daha kötü bir durumun önlenmesi ve psikolojik bir deneyimin gerçekleştirilmesiyle açıkladığı serbest zaman faydasının, üç ana boyutu Driver'ın "Serbest Zaman Faydaları Tipolojileri” olarak adlandırılmışıır ve "Rekreasyonda Algılanan Sağlık Çıktıları Ölçeğı” (RASÇÖ)'nin çatısını oluşturmak için kullanılmıştır. Rekreasyonda algılanan sağlık çıktılarının öncüsü rolündeki ölçek ise motivasyon teorilerine dayandırılan ve Driver tarafindan 1977'de ortaya konan "Rekreasyon Deneyimi Tercihi" ölçeğidir (Gómez ve diğ., 2016). Kavramsal olarak bakıldığında, rekreasyon aktivitelerinin çeşitli psikolojik ve fiziksel amaçlara ulaşmaya aracı olan davranışsal uğraşlar olduğu, problemli bir durumda bu problemin giderilmesi için rekreasyon aktivitelerine katılım amacı güdüldüğü kabul edilmektedir (örneğin stresten uzaklaşmak için balık tutmaya gidilmesi gibi) (Manfredo ve diğ., 1996). Bireylerin neden rekreasyonel uğraşlara katıldığını anlamaya yönelik çabalar, serbest zaman davranışını sadece bir aktiviteden çok, belirli bir ortamda psikolojik, sosyal ve fiziksel çıktılara yol açan bir deneyim olarak görmektedir (Budruk ve Stanis, 2013).

Rekreasyon deneyimi çeşitli çalışmalara konu olmuştur. Bir çalışmada rekreasyon deneyimi tercihi ölçeğinin bütünleyici bir biçimde yapısının ortaya konabilmesi için 36 çalışmadan oluşan bir meta-analizi çalışması yapılmış ve 328 maddelik bir havuza ulaşılmış, yapılan analizler sonucu 108 işlevsel maddeye ulaşılmıştır (Manfredo ve diğ., 1996). Bir başka çalışmada, gerçekleşen deneyimin, deneyim tercihine etkisi incelenmiş, doğa yürüyüşü tecrübesinden önce deneyim tercihi ölçümleri alınmış, verilen bir deneyimi başarabilenler ve başaramayanlar olarak iki gruba ayrılan deneklerden başaramayan grubun tercihlerinde azalma olduğu görülmüştür (Stewart, 1992). Büyük Kanyon Milli Parkında genel deneyim kalitesi ve diğer parametrelerin (gruplarla karşılaşma sayısı, kalabalık, yalnız kalma/mahremiyet) ilişkisinin incelendiği bir çalışmada düşük korelasyon olduğu ortaya konmuştur, fakat taşıma kapasitesine vurgu yapılmıştır (Stewart ve Cole, 2001). Zaman perspektifi ve rekreasyon deneyimi tercihleri ilişkisinin incelendiği bir çalışmada da zaman perspektifinin bazı fayda alt boyutlarıyla ilişkili olduğu ve serbest zaman araştırılmalarına zaman perspektifinin eklenmesi gerektiği ortaya konmuştur (Shores ve Scott, 2007). Park katılımcılarının deneyim tercihleri üzerine yapılan bir çalışmada da hem şehir hem de bölgesel parkları tercih eden katılımcıların doğadan zevk alma, kişisel/sosyal baskılardan kaçma, fiziksel baskılardan kaçma ve doğa sporu ikliminden yararlanma gibi temel tercihlere sahip olduğu ortaya konmuştur (Weber ve Anderson, 2010).

Burada yer verilmemiş olan birçok çalışmada rekreasyon deneyimi tercihleri ele alınmış ve Driver tarafindan geliştirilmiş olan ölçek kullanılmış olsa da bu ölçeğin daha geniş kabul görmesi için daha büyük örneklemlerde ve kültürler arası gruplarda kullanılarak geçerlik ve güvenirliğinin test edilmesi gerektiği belirtilmiştir (Alexandris ve diğ., 2009). Driver tarafindan 1983 ’te bu ölçeğin rekreasyon aktivitelerine ilk kez katılanların psikolojik deneyimini ölçmede 
eksik kaldığı, daha çok geçmişte deneyim sahibi olan rekreasyon katılımcılarına odaklanıldığı konusunda da bir eleştiri getirilmiş olması ve 328 madde ve 19 boyutla sahada veri toplamanın zorluğu, daha az ve öz, kolay uygulanabilir, teorik olarak desteklenen ve tamamlayıcı bir ölçeğe ihtiyaç duyulmasına yol açmıştır. 2006 yılında topladıkları veriyle Hill ve diğ. (2009) doğa yürüyüşü için motivasyon ve sağlık çıktılarını incelemiş, Freidt ve diğ. (2010) doğa yürüyüşünün faydaları ölçeğinin rekreasyon faydaları ile ilgili 30 sorusunu Driver'ın tipolojilerini (iyileştirilmiş durum, daha kötü bir durumun önlenmesi ve psikolojik deneyimin gerçekleşmesi) temel alarak faktör analizine tabi tutmuştur. $\mathrm{Bu} 30$ madde faktör yükleri dikkate alınarak 16 maddeye indirgenmiş̧ir. Hem bu 16 maddenin hem de üç boyutlu yapının sınanması için Gómez ve diğ. (2016) tarafından sırayla açımlayıcı, doğrulayıcı faktör analizleri ve ölçüm değişmezliği analizleri yapılmıştır. Bu analizlere göre ölçeğin üç boyutlu yapısı doğrulanmış ve 13 maddeli şekliyle ölçeğin geçerli ve güvenilir olduğu tespit edilmiştir.

Rekreasyonda algılanan sağlık çıktıları ölçeği literatürde 2016 yılından itibaren kullanılmaya başlanmış, park kullanıcılarına yönelik bir çalışmada, park kullanımı ile algılanan sağlık çıktıları ilişkisine bakılmış ve sağlık çıktıları içinde psikolojik deneyimin gerçekleşmesi boyutunun park kullanımını etkilediği tespit edilmiştir (Gómez ve Hill, 2016). $\mathrm{Bu}$ ölçek kullanılarak gerçekleştirilen bir başka çalışmada üniversite öğrencilerinin kaya tırmanış programlarıyla ilgili olarak algılanan sağlık çıktıları incelenmiş ve sonuçlara göre cinsiyete ya da tırmanılan mekâna bakılmaksızın katılımcıların tırmanıştan fayda sağladığı ortaya konmuştur (Berry ve diğ., 2019). Türkiye'de yapılan bir çalışmada çeşitli serbest zaman aktivitelerine katılan bireyler rekreasyonda algılanan sağlık çıktıları ve yaşam doyumu açısından incelenmiş, fiziksel aktivitelere katıldığını ifade eden bireylerde algılanan sağlık çıktılarının psikolojik deneyimin gerçekleşmesi alt boyutu açısından daha yüksek skorlar elde ettiği görülmüş, her üç alt boyutun da yaşam tatminiyle pozitif yönde anlamlı korelasyon gösterdiği ortaya konmuştur (Elçi ve diğ., 2019). Alanyazında yer alan bu çalışmalar incelendiğinde; her ne kadar ölçeğin farklı kültürlerde adaptasyonuna rastlanmamış olsa bile, uluslararası alanyazında bu konuyla ilgili çalışmaların azımsanmayacak kadar çok ama yurtiçindeki alanyazında son derece az olduğu söylenebilir.

Bu nedenle ülkemizde rekreasyon ve spor aktivitelerine yapılacak yatırımların artması, yeni tesislerin geliştirilmesi veya iyi uygulamaların yönetim ve programlama açısından örnek olarak alınması açısından bu faaliyetlerin gerek sağlık gerekse yaşam kalitesi açısından objektif ve ölçülebilir çıktılarla değerlendirilmesi önem taşımaktadır. Dolayısıyla bu tarz bir ölçüm aracının kültürümüzde de faydalı olacağı düşünülmektedir. Bu bağlamda bu çalışmanın amacı Rekreasyonda Algılanan Sağlık Çıktıları ölçeğinin Türk diline adapte edilerek, Türk kültürüne yönelik geçerli ve güvenilir bir ölçek elde edilmesidir.

\section{YÖNTEM}

Araştırmacılar bu çalışmayı yapısalcı paradigma bağlamında ele almışlardır (Günbayı ve Sorm, 2018). Ölçme aracının uyarlanması ile elde edilen verilerin çözümlemesinin yapılması, ölçeğe ilişkin faktör yapısının araştırmanın amacı doğrultusunda betimlenmesi nedeniyle, çalışmanın düzeyine göre betimsel bir çalışma olup tarama modeli ile yapıldığ ifade edilebilir (Büyüköztürk ve diğ., 2014).

Araştırma Grubu: Araştırmanın örnekleminin belirlenmesinde amaçlı örnekleme yöntemlerinden kolayda örnekleme tekniği kullanılmıştır. Kolayda örnekleme tekniğinin tercih edilmesindeki önemli husus araştırmacıların para, zaman ve iş gücü kaybını mümkün olan en asgari düzeye indirmektir (Ravid, 1994). Bu çalışmada ölçeğin RASÇÖ’nün üç faktörlü yapısının psikometrik özelliklerini ortaya koymak amacıyla AFA ve DFA analizi yapılmıştır. Bu bağlamda örneklem belirlenirken AFA ve DFA analizi için ayrı ayrı iki veri toplanmıştır. Araştırma örneklemini oluşturan iki grup da aynı platformun düzenli olarak organize ettiği açık hava rekreasyon etkinliğine katılan ve düzenli olarak haftada en az iki kez koşan bireylerden oluşmaktadır. İlk grup 166 kadın ve 179 erkek olmak üzere toplam 345 katılımcıdan (kadınyaş 
ort $=31.59 \pm 9.36$, erkekyaş ort $=34.36 \pm 11.10$, toplamyaş ort $=33.02 \pm 10.38$ y1l), ikinci grup ise 91 kadın ve 109 erkek olmak üzere toplam 200 katılımcıdan (kadınyaş ort=33.24 \pm 8.71 , erkekyaş ort=33.18 \pm 9.03 , toplamyaş ort=33.21 $\pm 8.87 \mathrm{y} 1$ ) oluşmaktadır.

Veri Toplama Araçları: Gómez ve diğ tarafından 2016 yılında geliştirilen ve rekreasyona dayalı algılanan psikolojik ve ruhsal sağlığa ilişkin fayda teorilerini temel alarak oluşturulan RASÇÖ (The Perceived Health Outcomes of Recreation Scale) 13 madde ve 3 alt boyuttan oluşan Likert tipi bir ölçektir. Fakat adaptasyon çalışması yapılırken araştırmacılardan nihai değil denemelik form istenmiştir. Denemelik form 16 maddeden oluşmaktadır. Adaptasyon sürecinde 16 maddenin de Türk kültüründe çalıştığı tespit edilmiş bu nedenle geçerlik ve güvenirlik analizleri 16 madde üzerinden yapılmıştır. Ölçeğin her bir maddesine ilişkin cevaplama (1) kesinlikle beni ifade etmiyor; (7) Tamamen beni ifade ediyor arasında yapılmaktadır. Ölçeğin alt boyutları; “psikolojik deneyimin gerçekleşmesi (PDG)”, "daha kötü bir durumun önlenmesi (DKDÖ)" ve "iyileştirilmiş durum (ID)" dan oluşmaktadır. Ölçek sadece alt boyut puanlarının ortalamaları ile değerlendirilmektedir. Ölçeğin orijinali için yapılan DFA sonuçları CFI=.95, RMSEA=.050, SRMR=.090 olarak hesaplanmıştır. Cronbach alfa katsayıları ise .85 ile .89 arasında değişmektedir. Ayrıca ölçeğe ilişkin standardize edilmiş katsayıların .34 ile .85 arasında; gizil değişkenler arasındaki korelasyonların ise .38 ile .59 arasında değiştiği saptanmıştır.

İşlem Yolu: Ölçek, AFA ve DFA analizlerinin yapılabilmesi için düzenli egzersiz katılımcılarından sırasıyla toplam 345 ve 200 kişiden oluşan iki grup yetişkin bireye uygulanmıştır. Veri toplama süreci yüz yüze gerçekleştirilmiş, çalışmanın amacıyla ilgili bilgilendirme yapılmış ve gönüllü katılım onayı alınmıştır.

Verilerin Analizi: Yapılan çalışmada veri analizi sırasında, AFA analizi için SPSS, DFA analizi için de LISREL paket programları kullanılmıştır. Verilerin analizinde, pearson korelasyonu, bağımlı gruplarda t-testi ve yapılmış asıl uygulamadan elde edilen veriler üzerinde ise faktör analizi uygulanmıştır. Bununla birlikte iç tutarlılık güvenirlik katsayısı (Cronbach Alfa), bileşik güvenirlik katsayısı, ortalama açıklanan varyans (AVE), maksimum paylaşılan varyansın karesi (MSV) ve AVE değerinin karekökü hesaplanmıştır.

Araştırmanın yapılabilmesi için bazı sayıltıların test edilmesi gerekmektedir. Kline (2005)'a göre faktör analizi öncesinde ortaya çıkacak problemleri asgari düzeye indirmek için; örneklem büyüklüğü değerlendirilmiş, normallik koşullarının sağlanıp sağlanmadığına bakılmış, kayıp değerler ve uç değerler problemine ilişkin sayıltılar değerlendirilmiş son olarak çoklu bağlantı problemi olup olmadığına bakılmıştır.

Verilerin basıklık ve çarpıklık katsayıları -1 ile +1 arasında bir değer almaktadır. Bu doğrultuda verilerin büyük oranda normal dağıldığı ifade edilebilir (Tabachnick ve Fidell, 2007; Rosenthal ve Rosnow, 2008). Faktör analizinin diğer bir sayıltısı örneklem büyüklüğüdür. Örneklem büyüklüğüne ilişkin farklı birçok görüş bulunmaktadır (Comrey ve Lee, 1992; Kline, 2005). Bu görüşler altında n=545 örneklem sayısının faktör analizi yapmak için uygun olduğu ifade edilebilir.

Çalışmanın bir sonraki sayıltısı ise kayıp değerlerin tespitidir. Araştırmacılar kayıp verileri incelerken bu verilerin sistematik bir şekilde dağılmadığını tespit etmiştir. Bununla birlikte kayıp veri oranı \% 1.5 'den azdır. Uç değerlerin tespit edilmesi için de mahlonobis uzaklığından yararlanılmış ve uç değer olarak tespit edilen veriler analize dahil edilmemiştir. Diğer sayıltılar olan çok değişkenli normallik, doğrusallık ve eş varyanslılık sayıltıları karşılanmış ve çoklu bağlantı probleminin olmadığı tespit edilmiştir (VIF $<5$; CI $<30$ ).

Temel sayıltıların karşılanmasından sonra AFA ve DFA analizleri yapılmıştır. AFA bir grup değişken için bir faktör modeli ya da yapısını tanımlarken (Bandalos,1996), DFA'nın amacı ise faktör yapısını tanımlamak değil, modelin gözlenen ve gözlenemeyen tüm değişkenlerinin birlikte test edilmesi ile elde edilen sonucun, eldeki verilerle ne derece uyumlu olduğunun ortaya konulmasını sağlamaktır (Özdamar, 2016). Araştırmaya ilişkin son analiz ise ölçeğin yapı 
geçerliğini ortaya koymak için yakınsak ve ıraksak geçerlik çalışmalarıdır. Yakınsak geçerlik, değişkenlerde yer alan ifadelerin birbirleri ve oluşturmuş oldukları faktörler ile ilişkilisini ifade eden bir kavramdır (Coşkun ve diğ., 2010). Yakınsak geçerliğin sağlanmasında CR ve AVE değerleri hesaplanmıştır. Yakınsak geçerliğin sağlanabilmesi için CR >AVE; AVE $>0,5$ olmalıdır. Iraksak geçerlilik değişkenlere ilişkin ifadelerin ait oldukları faktör dışındaki faktörlerle kendi bulundukları faktörden daha az ilişkili olması gerekliliğidir (Yaşlığlu, 2017). Iraksak geçerliğin sağlanması için iki yeni değerin daha hesaplanması gerekmektedir. Bunlardan biri MSV diğeri ise ASV değeridir. Iraksak geçerliğin varlığından söz edebilmek için de $\mathrm{MSV}<\mathrm{AVE}$; $\mathrm{ASV}<\mathrm{M} \neg \mathrm{SV}$ olmalı ve aynı zamanda $\mathrm{AVE}$ ’nin karekökünün de faktörler arası korelasyondan büyük olması gerekmektedir.

Dilsel Geçerliği: RASÇÖ’nün uyarlaması için Edwin Gomez'den gerekli izinler alındıktan sonra çalışma üç aşamalı olarak yürütülmüştür. Çalışmanın ilk aşaması dilsel eşdeğerliğin sağlanmasıdır. Daha sonra uzman görüşüne ve asıl uygulama süreçleri ile çalışmaya devam edilmiştir. Çalışmanın her bir aşaması için gönüllük esas alınmıştır.

Dilsel eşdeğerliğin sağlanmasına ilişkin iki yöntemden bahsedilebilir. Bu iki yöntemden biri uzman görüşü diğeri ise istatistiksel tekniklerin kullanılmasıdır. Eğer her iki dile de hakim uzman sayısı ile ilgili bir sorun varsa alan uzmanlarının görüşlerine başvurulmaktadır. Ancak ilgili çalı̧̧mada her iki dile hakim örnekleme ulaşılması nedeniyle dil eşdeğerliği için istatistiksel tekniklere başvurulmuştur (Seçer, 2015). Orijinal ölçek, ölçeğin uygulama ve puanlaması için hazırlanan yönergeler, "Rekreasyon" alanlarında akademisyen olarak çalışan ve üniversite eğitimini İngilizce olarak yapmış olan iki kişi tarafından birbirinden bağımsız bir şekilde Türkçe çevirisi yaptırılmıştır. Daha sonra çeviri İngilizce dilbilim uzmanı iki kişi ve rekreasyon alanında çalışan ve İngilizce seviyesi akademik yeterliliğge sahip olan üç akademisyen tarafından değerlendirilmiştir. Oluşturulan Türkçe formu, üç dilbilim uzmanı tarafından tekrar İngilizce'ye çevrilmiştir. Ölçeğin orijinal hali ile tekrar İngilizce'ye çevrilmiş hali "Rekreasyon" alanlarında çalş̧an ve İngilizce düzeyi akademik yeterliliğe sahip olan üç akademisyene incelettirilerek, ikisi arasında farkl1lığın olmadığı yönünde ortak görüşe varılmıştır. Uzman görüşü referans alınarak elde edilen ölçeğin Türkçe formu ile İngilizce formunun aynı anlamı ifade edip etmediğini, uygulamada görebilmek açısından, iyi derecede İngilizce bilgisine sahip akademisyen, doktora ve yüksek lisans öğrencisi 20 kişiye uygulanmış ve her iki ölçekten alınan puanlar arasında pearson momentler çarpımı korelasyon katsayısı ve iki eş arasındaki farkın anlamlılık testi sonuçları hesaplanmıştır. Elde edilen korelasyon katsayısına $(\mathrm{r}=.90$, $\mathrm{p}=.000) \mathrm{t}$-testi sonucuna $(\mathrm{t}=2.83, \mathrm{p}=.011)$ ve uzman görüşlerine bakılarak ölçeğin çeviri açısından paralelliğin sağlandığı kabul edildikten sonra Türkçe forma son hali verilmiştir. Elde edilen ampirik kanıtlar ile RASÇÖ’nün dilsel eşdeğerliğinin sağlandığı ifade edilebilir. Bu aşamalara ilişkin yapılan istatistiksel analizler Tablo 1 de verilmektedir.

Tablo 1. RASÇÖ’nun Türkçeye uyarlanma süreci

\begin{tabular}{|ll|}
\hline İznin Alınması & Edwin Gómez 9 Aralık 2016 tarihinde izin alınmıştır. \\
Türkçe Formun oluşturulması & $\begin{array}{l}\text { Hambleton ve Patsula (1999) tarafından önerilen } \\
\text { adımların takip edilmesi }\end{array}$ \\
Geçerlik Çalışmaları & $\begin{array}{l}\text { Yapı geçerliği, yakınsak geçerlik, raksak geçerlik } \\
\text { Güvenirlik Çalışmaları }\end{array}$ \\
Madde Analizi & $\begin{array}{l}\text { Cronbach alfa kat sayısı, bileşik güvenirlik katsayısı } \\
\text { karşıltilmiştış madde toplam korelasyonunun \%27 alt ve üst }\end{array}$ \\
\hline
\end{tabular}

Pilot Çalışma: Çalışmanın ikinci aşaması ise ölçeğin Türkçe formuna ilişkin pilot çalışmadır. Pilot uygulama 20162017 yılı güz döneminde, spor bilimleri fakültesinde öğrenim gören 20 öğrenciye uygulanmış ve uygulama esnasında ölçeğin cevaplanmasına ilişkin bir süre belirlenmemiştir. 
Bu uygulamadaki iki temel amaç; 1- ölçeğe ilişkin sorularının yanıtlanması için ihtiyaç duyulan sürenin saptanması; 2- Ölçek sorularının anlaşılırlığına ilişkin gelen yanıtlar dikkate alınarak ölçeğe son halinin verilmesidir. Çalışmanın üçüncü aşaması ise asıl uygulamanın yapıldı̆̆ı aşamadır. Bu aşamada AFA ve DFA analizine ilişkin tüm sayıltılar test edilmiş ve toplam 637 kişiye ulaşılmıştır. Temel sayıltıların test edilmesi sürecinde uç değer olduğu tespit edilen 92 kişinin çalışmadan çıkarılmasına karar verilmiş ve çalışma toplam 545 kişi ile tamamlanmıştır.

\section{BULGULAR}

Açımlayıcı Faktör Analizi: RASÇÖ’nün yapı geçerliğini ortaya koymak amacıyla öncelikli olarak AFA analizi yapılmıştır. AFA yapmadan önce örneklem büyüklüğünün, faktörleştirme için uygun olduğunu sınamak amacıyla KaiserMeyer-Olkin $(\mathrm{KMO})$ testi yapılmıştır. Yapılan KMO ve Bartlett testlerinde $\mathrm{KMO}=.89, \chi^{2}=3370.88, \mathrm{df}=120, \mathrm{p}=.000 \mathrm{olarak}$ hesaplanmış ve sonuçların faktör analizi için uygun olduğu saptanmıştır. KMO değerinin .89 olması örneklem büyüklüğünün yeterli olduğunu ifade etmektedir (Çokluk ve diğ., 2016). Açımlayıcı faktör analizinde faktörleştirme yöntemi olarak varimax döndürme tekniği kullanılmış ve sonuçlar değerlendirilirken özdeğeri $>1.0$ olan faktörler değerlendirmeye alınmıştır. Varimax döndürmesine göre, ölçeğin 3 faktörde toplandığı ve toplam varyansın \%66.34'ünü açıkladığı saptanmıştır. Ancak faktör sayısına karar vermeden önce her bir faktörün toplam varyansa yaptı̆̆ı katkı göz önünde bulundurulmalıdır. Buna göre birinci faktör toplam varyansın \%25.98'ini; ikinci faktör toplam varyansın \%22.30'unu ve üçüncü faktör toplam varyansın \%18.05'ini açıklamakta ve ikinci faktör ile üçüncü faktörün toplam varyansa yaptığı katkı giderek azalmaktadır. Faktör sayısına karar vermek için değerlendirilen bir diğer husus ise yamaç birikinti grafiğidir (Şekil 1).

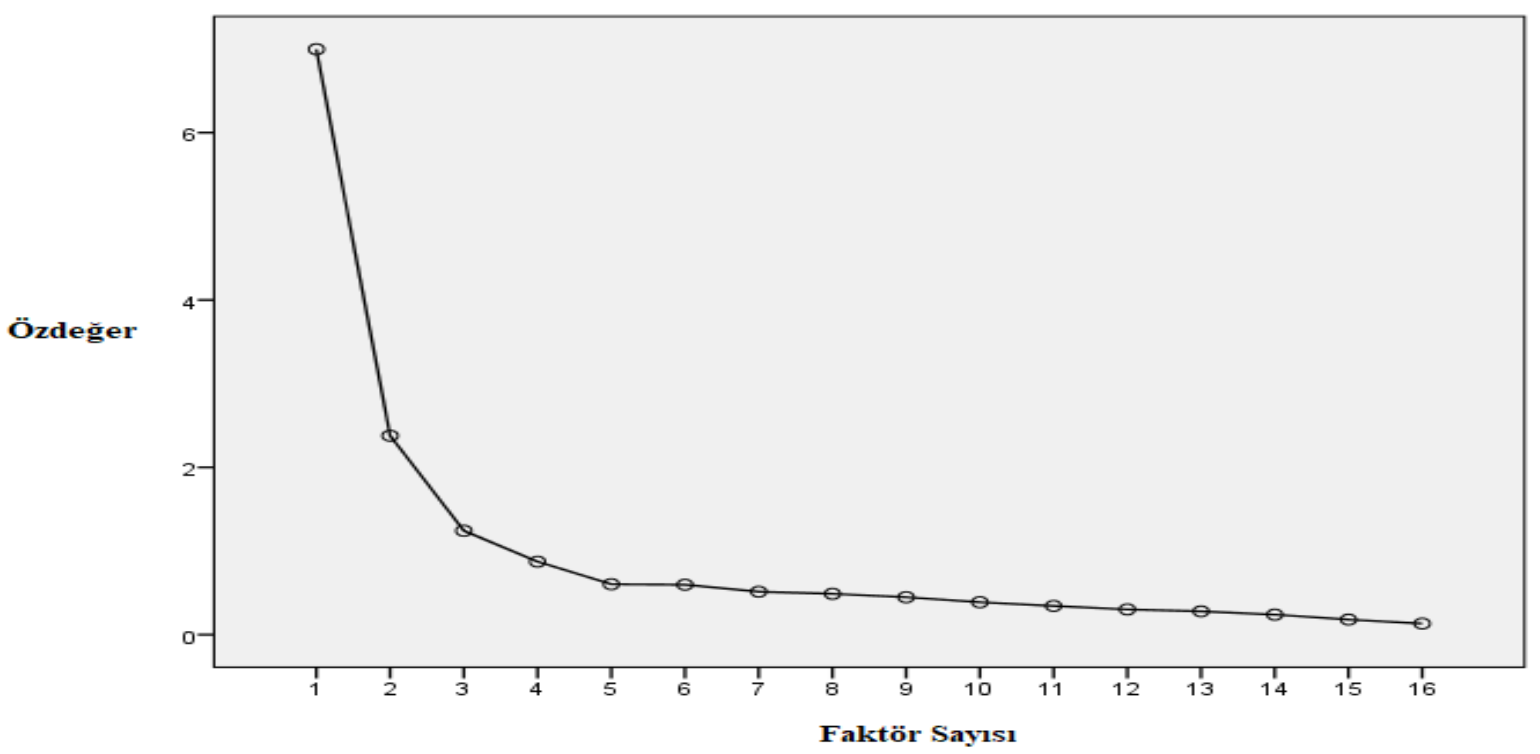

Şekil 1. Yamaç birikinti grafiği

Faktörlerin toplam varyansa yaptığı katkı göz önüne alındığında ve yamaç birikinti grafiği incelendiğinde faktör sayısının üç olarak belirlenmesine karar verilmiştir. AFA analizi yapılırken genellikle çok faktörlü desenlerde binişik olan maddeler olabilir ya da faktör yük değerleri belirlenen kesme noktasının altında kalabilir. Ancak faktör analizi sonuçları, faktör yük değerlerinin düşük olmadığını ve binişik maddelerin bulunmadığını ortaya koymuştur.

RASÇÖ’nün 16 madde ve üç faktörlü yapısına ilişkin faktör deseni, faktör yük değerleri ve ortak faktör varyansları detaylı bir şekilde Tablo 2'de verilmektedir. 
Tablo 2. RASÇÖ faktör analizi sonuçları (Temel bileşenler analizi-Varimax)

\begin{tabular}{|c|c|c|c|c|}
\hline Faktörler & Madde No & Faktör Ağırlıkları & Faktör Açıklayıcıları & Cronbach Alfa \\
\hline \multirow[t]{7}{*}{ Faktör 1} & PDG_4 & .768 & \multirow{7}{*}{25.985} & \multirow{7}{*}{.89} \\
\hline & PDG_5 & .748 & & \\
\hline & PDG_1 & .732 & & \\
\hline & PDG_3 & .728 & & \\
\hline & PDG_2 & .728 & & \\
\hline & PDG_6 & .711 & & \\
\hline & PDG_7 & .667 & & \\
\hline \multirow[t]{5}{*}{ Faktör 2} & DKDÖ_4 & .868 & \multirow{5}{*}{22.307} & \multirow{5}{*}{.81} \\
\hline & DKDÖ_3 & .840 & & \\
\hline & DKDÖ_1 & .795 & & \\
\hline & DKDÖ_2 & .766 & & \\
\hline & DKDÖ_5 & .710 & & \\
\hline \multirow[t]{4}{*}{ Faktör 3} & İD_2 & .756 & \multirow{4}{*}{18.057} & \multirow{4}{*}{.91} \\
\hline & İ_4 & .719 & & \\
\hline & İD_1 & .711 & & \\
\hline & İD_3 & .656 & & \\
\hline \multicolumn{3}{|l|}{ Toplam } & 66.34 & \\
\hline \multicolumn{3}{|c|}{ Kaiser Meyer Olkin Ölçek Güvenirliği: } & .89 & \\
\hline \multicolumn{3}{|c|}{ Bartlett Küresellik Testi Ki Kare: } & 3370.88 & \\
\hline \multicolumn{3}{|l|}{ Sd: } & 120 & \\
\hline \multicolumn{3}{|l|}{$\mathbf{P}$} & .000 & \\
\hline
\end{tabular}

Tablo 2 incelendiğinde alt ölçekler düzeyindeki faktör yük değerleri görülmektedir. Buna göre psikolojik deneyimin gerçekleşmesi alt ölçeği için faktör yük değerleri .66 ile .76 arasında; daha kötü bir durumun önlenmesi alt ölçeği için .71 ile .86 arasında ve son olarak iyileştirilmiş durum ölçeği için .65 ile .75 arasınadır. Faktör yüklerinin büyüklüğü incelendiğinde yük değerleri için “iyi”’den “mükemmel”e şeklinde yorumlamak olanaklıdır (Tabachnick ve Fidell, 2007). Sosyal bilimler alanında yapılan ölçek geliştirme çalışmalarında özellikle çok faktörlü desenlerde açıklanan varyansın \%40 ile \%60 arasında olması yeterli olarak kabul edilmektedir (Büyüköztürk, 2011). Bu bağlamda açıklanan toplam varyansın yeterli olduğu söylenebilir.

Tablo 3. RASÇÖ alt ölçekler arası korelasyon matrisi

\begin{tabular}{lccc}
\hline & PDG & DKDÖ & ID \\
\hline PDG & 1 & & \\
DKDÖ & .231 & 1 & 1 \\
ID & .542 & .379 & 1 \\
\hline
\end{tabular}

Tablo 3 incelendiğinde RASÇÖ’ye ilişkin alt ölçekler arasındaki ilişkiler görünmektedir. Buna göre alt ölçekler arasındaki korelasyonların .231 ile .542 arasında değiştiği saptanmıştır. Elde edilen bu ilişkilerin tümü manidardır $(p=.000)$. 


\section{Madde Analizi:}

Tablo 4. Maddelerin ayırt ediciliği

\begin{tabular}{lcc}
\hline Maddeler & $\boldsymbol{t}$ & $\boldsymbol{p}$ \\
\hline Madde 1 & 8.042 & .000 \\
Madde 2 & 9.287 & .000 \\
Madde 3 & 10.338 & .000 \\
Madde 4 & 9.968 & .000 \\
Madde 5 & 8.700 & .000 \\
Madde 6 & 8.373 & .000 \\
Madde 7 & 10.965 & .000 \\
Madde 8 & 10.405 & .000 \\
Madde 9 & 10.126 & .000 \\
Madde10 & 10.517 & .000 \\
Madde 11 & 6.677 & .000 \\
Madde 12 & 7.292 & .000 \\
Madde 13 & 11.516 & .000 \\
Madde 14 & 11.092 & .000 \\
Madde 15 & 7.689 & .000 \\
Madde 16 & 10.114 & .000 \\
\hline
\end{tabular}

Katılımcıların \%27'lik alt ve üst gruplarının belirlenmesi için ölçekten alınan ortalama puanlar büyükten küçüğe doğru sıralanmıştır. RASÇÖ ölçeğinin \%27'lik kısmına gelen en düşük puanlı 64 kişi ile en yüksek puanlı 64 kişi incelenmiştir. Maddelerin ayırt ediciliğinin kararının verilmesinde kullanılan \%27’lik alt ve üst değerlerinin tüm maddeler için anlamlı olduğu belirlenmiştir $(\mathrm{p}=.000)$.

Doğrulayıcı Faktör Analizi: RASÇÖ’nün yapı geçerliğine ilişkin bir başka kanıt ise yapılan DFA analizi sonuçlarıdır. Analize ilişkin standardize edilmiş katsayılar ve hata varyansları Şekil 2.'de verilmektedir.

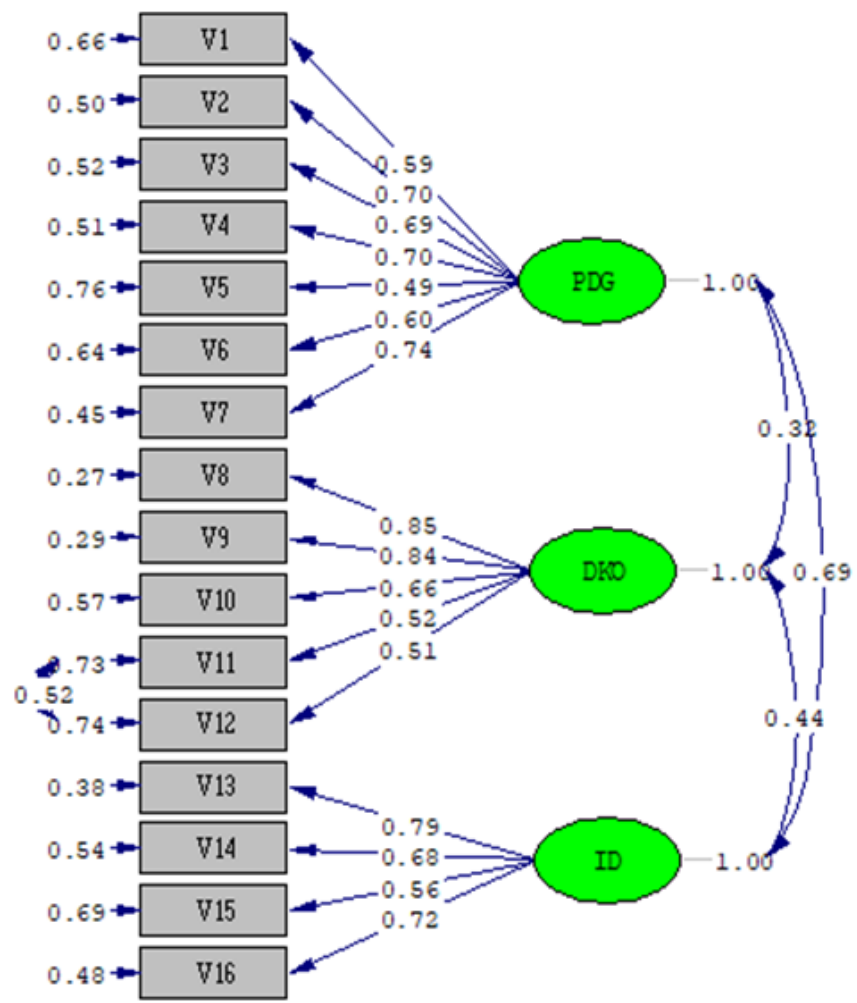

Chi-Square $=197.51, \mathrm{df}=100, \mathrm{P}$-value $=0.00000, \mathrm{RMSEA}=0.063$

Şekil 2. Doğrulayııı faktör analiz sonuçları 
Şekil 2'de görüldüğü üzere RASÇÖ’nün standardize edilmiş katsayıları .49 ile .85 arasında; hata varyansları ile .27 ile .76 arasında değişmektedir. DFA analizi sonucunda incelenen modifikasyon indeksleri içinde 11. ve 12. göstergeler arasında modifikasyon yapılmasına karar verilmiş ve yapılan modifikasyonun ki-kare değerine manidar bir katkı sağladığı saptanmıştır. Modifikasyon öncesi ve sonrası DFA analizine ilişkin uyum indeksleri Tablo 5'de verilmiştir. Ayrıca göstergelerin standardize edilmiş katsayıları incelendiğinde tüm maddelerin t değerlerinin 7.62 ile 15.21 arasında olduğu ve manidar olduğu saptanmıştır. Bu durum DFA analizi sonrası maddelerin ilgili oldukları faktörleri \%99 güven aralığında doğruladığı saptanmıştır ( $\mathrm{p}=.000)$. Son olarak DFA uyum indeksleri değerlendirilirken RMSEA değerinin \%95 güven aralığında alabileceği değerin .03 ile .08 aralığında olması gerektiği kabul edilirken (Rigdon, 1996), modifikasyon sonrası bu değerin .063 ile uygun aralıkta olduğu görülmektedir.

Tablo 5. Birinci düzey doğrulayıcı faktör analizi uyum indeksleri

\begin{tabular}{lccccccccc}
\hline & $\chi^{\mathbf{2}}$ & $\boldsymbol{d} \boldsymbol{f}$ & $\boldsymbol{\chi}^{\mathbf{2} / \boldsymbol{d} \boldsymbol{f}}$ & GFI & NFI & TLI & CFI & RMSEA & SRMR \\
\hline Modifikasyondan önce & 358.17 & 101 & 3.54 & .85 & .89 & .90 & .92 & .102 & .078 \\
Modifikasyondan sonra & 197.51 & 100 & 1.56 & .91 & .94 & .96 & .97 & .063 & .059
\end{tabular}

DFA sonrasında değerlendirilen bir diğer husus maddelerin örtük yapıya olan katkılarıdır. Bu bağlamda maddelerin standart yükleri ve örtük değişkeni açıklama düzeyleri değerlendirilmiştir. RASÇÖ’ye ilişkin maddeler incelendiğinde örtük değişkeni en fazla açıklayan maddenin 8. Madde (diyabet /şeker hastası olma riskimi azaltır) olduğu tespit edilmiştir. Ölçek maddelerinin standartlaştırılmış yükleri, t değerleri ve r2 değerleri ayrıntılı olarak Tablo 6'de verilmektedir.

Tablo 6. RASÇÖ’ya ilişkin birinci düzey ölçme modeli sonucu

\begin{tabular}{lccc}
\hline Faktör Madde & Standartlaştırılmış Yükler & $\boldsymbol{t}$-değeri & $\boldsymbol{r}^{\mathbf{2}}$ \\
\hline PDG_1 & .59 & 9.40 & .34 \\
PDG_2 & .70 & 11.88 & .49 \\
PDG_3 & .69 & 11.58 & .47 \\
PDG_4 & .70 & 11.76 & .49 \\
PDG_5 & .49 & 7.62 & .24 \\
PDG_6 & .60 & 9.75 & .36 \\
PDG_7 & .74 & 12.73 & .54 \\
DKDÖ_1 & .85 & 15.21 & .72 \\
DKDÖ_2 & .84 & 14.93 & .70 \\
DKDÖ_3 & .66 & 10.91 & .43 \\
DKDÖ_4 & .52 & 8.10 & .27 \\
DKDÖ_5 & .51 & 7.93 & .26 \\
ID_1 & .79 & 13.42 & .62 \\
ID_2 & .69 & 11.13 & .47 \\
ID_3 & .58 & 8.68 & .33 \\
ID_4 & .72 & 11.97 & .51 \\
\hline
\end{tabular}

Birinci düzey DFA analizi sonrasında ikinci düzey DFA analizi yapılmıştır. Böylelikle RASÇÖ’nün üç gizil değişkeni olan psikolojik deneyimin gerçekleşmesi, daha kötü bir durumun önlenmesi ve iyileştirilmiş durumu ne ölçüde açıkladığı belirlenmiştir (Tablo 7).

Tablo 7. İkinci düzey faktör analizi uyum indeksleri

\begin{tabular}{lccccccccc}
\hline & $\chi^{2}$ & $d f$ & $\chi^{2} / d f$ & GFI & NFI & TLI & CFI & RMSEA & SRMR \\
\hline İkinci Düzey DFA & 358.17 & 101 & 3.54 & .91 & .94 & .96 & .97 & .063 & .059 \\
\hline
\end{tabular}


İkinci düzey DFA sonuçları incelendiğinde; ikinci düzey olan RASÇÖ ile birinci düzey değişkenler arasındaki ilişkilerin tümünün anlamlı olduğu, en yüksek ilişkinin ise iyileştirilmiş durum gizil değiş̧keni ile olduğu saptanmıştır $(\beta=.91, \mathrm{t}=8.51)$. İkinci düzey DFA'ya ilişkin standartlaştırılmış yükler $\mathrm{t}$ ve $\mathrm{r} 2$ değerleri Tablo 8'de verilmektedir.

Tablo 8. RASÇÖ’ye ilişkin ikinci düzey ölçme modeli sonucu

\begin{tabular}{llccc}
\hline İkinci Düzey Değişken & \multicolumn{1}{c}{ Birinci Düzey Değişken } & Yol katsayısı & $\boldsymbol{t}$-değeri & $\boldsymbol{r}^{\mathbf{2}}$ \\
\hline \multirow{3}{*}{ RASÇÖ } & Psikolojik deneyimin gerçekleşmesi & .71 & 6.40 & .50 \\
& Daha kötü bir durumun önlenmesi & .46 & 5.73 & .21 \\
& İyileştirilmiş durum & .97 & 8.51 & .26 \\
\hline
\end{tabular}

Yakınsak ve Iraksak Geçerlik: Yakınsak geçerlik değerlendirildiğinde, CR değerinin .70 üzerinde olduğu görülmektedir. Cronbach Alfa gibi CR`1n da .70’in üzerinde olması ölçeğin güvenirliğine ilişkin ek bir ampirik kanıt sağlamaktadır (Raykov, 1998).

Tablo 9. Yakınsak ve raksak geçerlilik testi sonuçları

\begin{tabular}{lccccc}
\hline & CR & AVE & AVE KAREKÖK & MSV & ASV \\
\hline PDG & .83 & .41 & .64 & .47 & .25 \\
DKDÖ & .83 & .50 & .71 & .22 & .12 \\
ID & .78 & .47 & .68 & .46 & .34 \\
\hline
\end{tabular}

Bununla birlikte faktörlere ilişkin tüm CR değerlerinin AVE değerlerinden büyük olduğu tespit edilmiştir. Bununla birlikte "Daha kötü bir durumun önlenmesi” alt boyutu hariç diğer iki alt boyut olan "psikolojik deneyimin gerçekleşmesi” ve "iyileştirilmiş durum” alt boyutlarında AVE değerinin kritik değer olan .50'nin altında olduğu tespit edilmiştir. Ancak diğer güvenirlik kriterlerinin sağlanması nedeniyle AVE değerinin .50’nin biraz altında kalmış olmasının kabul edilebilir olduğu ifade edilmektedir (Fornell ve Larcker, 1981). Araştırma bulgularına dayanarak yakınsak geçerliğin sağlandığı ifade edilebilir.

Iraksak geçerlik için Tablo 9 incelendiğinde ise psikolojik deneyimin gerçekleşmesi alt boyutu hariç tüm MSV değerlerinin AVE değerinden küçük olduğu, tüm alt boyutlar dahilinde ASV değerlerinin MSV değerlerinden küçük olduğu ve son olarak yine tüm alt boyutlar dahilinde AVE'nin karekökünün faktörler arası korelasyondan büyük olduğu tespit edilmiştir. Elde dilen bulgular dahilinde ıraksak geçerliğin sağlanmasına ilişkin koşulların da yerine geldiğini söylemek mümkündür.

\section{TARTIŞMA}

Yapılan çalışmanın amacı Gómez ve diğ. (2016) tarafından geliştirilen RASÇÖ’nün, Türkçe versiyonunun geçerlik ve güvenirliğinin incelenmesidir. Çalışmanın uyarlanmasında ilk aşama olan dilsel eşdeğerlik incelenmiştir. Bu amaç dahilinde ölçeğin orijinal formu ile Türkçe formu arasındaki korelasyon kat sayısı ile yine bu iki form üzerinden alınan puanların manidarlığı test edilmiştir. Analizden elde edilen bulgular ölçeğin orijinal formu ile Türkçe formu arasındaki korelasyon katsayısının oldukça yüksek olduğunu ve yine bu iki formdan elde edilen puanlar arasındaki farkın ölçek maddelerinin hiçbirinde manidar olmadığı saptanmıştır. Analiz sonuçları, ölçeğin Türkçe formunda yer alan maddelerin İngilizce formunda yer alan maddeler ile benzeştiğini ve her iki formun da dilsel açıdan eş değerliğini ortaya koymaktadır. 
Ölçeğin yapı geçerlik sonuçlarından ilki olan AFA analizi sonuçları; yapının üç faktörlü olduğunu ortaya koymaktadır. RASÇÖ ölçeğinin orijinal formu da benzer şekilde üç faktörlü yapıdan oluşmaktadır. Elde edilen bu üç faktör ise toplam açılanan varyansın \%66.34'ünü oluşturmaktadır. Sosyal bilimler alanında yapılan ölçek geliştirme çalışmaları için açıklanan varyansın \%40 ile \%60 arasında olmasının yeterli olduğu göz önüne alınırsa elde edilen varyansın yeterli olduğu düşünülmektedir (Tabachnick ve Fidell, 2007; Büyüköztürk, 2011).

Ölçeğin üç faktörlü yapısının düzenli egzersiz yapan bireyler üzerinde doğrulanıp doğrulanmadığını ortaya koymak için yapılan DFA analizi sonuçları ise yapıyı desteklemektedir. Birinci düzey DFA analizi ölçeğin orijinal formundaki gibi üç faktörlü yapısını doğrulamıştır. Bununla birlikte, Türkçe uyarlaması yapılan ölçek maddelerinin orijinal formdaki maddeler ile örtüş̧üğü tespit edilmiştir. Birinci düzey DFA analizi ile elde edilen üç alt boyutun bir üst yapı olan RASÇÖ örtük değişkeni ile ne kadar uyum sağladığı ortaya koymak amacıyla ikinci düzey DFA yapılmıştır. Buna göre birinci ve ikinci düzey DFA analiz sonuçlarından elde edilen uyum indekslerinin hem kabul edilebilir ve mükemmel uyum indeksleri arasında yer aldığı hem de birbirine yakın olduğu saptanmıştır ve uyum yeterliğinin iyi olduğu tespit edilmiş̧tir. Yapı geçerliğini sağlamak amacıyla yakınsak ve ıraksak geçerliğe bakılmış bu bağlamda CR, ASV, MSV, AVE ve AVE karekökü hesaplanmıştır. Yakınsak geçerlik için CR>AVE; AVE >.50 olması gerekmektedir. Tüm CR değerlerinin AVE değerlerinden büyük olduğu ancak iki alt boyuttan elde edilen AVE değerlerinin kritik değer olan .50'ye yakın olduğu tespit edilmiştir. Ancak, diğer güvenirlik kriterlerinin sağlanması ile yakınsak geçerliğin büyük ölçüde sağlandığı ifade edilebilir. Iraksak geçerlik için sağlanması gereken koşullar ise ASV $<\mathrm{MSV}$, MSV $<\mathrm{AVE}$ ve AVE değerinin karekökünün faktörler arası korelasyondan büyük olmasıdır (Yaşlığlu, 2017). Elde edilen bulgular incelendiğinde psikolojik deneyimin gerçekleşmesi alt boyutu dışında MSV $<$ AVE koşulu sağlanmıştır. Bununla birlikte, ASV $<$ MSV koşulu da her alt boyut için sağlanmış ve son olarak AVE'nin karekökünün faktörler arası korelasyondan büyük olduğu tespit edilmiştir. Elde edilen sonuçlar dahilinde yapı geçerliğinin sağlandığı ifade edilebilir. Yakınsak ve Iraksak geçerliğe yönelik tüm sonuçlar orijinal ölçeğin sonuçları ile karşılaştırıldığında, orijinal ölçeğin de tüm AVE değerlerinin .50'nin üzerinde, tüm $\mathrm{CR}$ değerlerin $\mathrm{AVE}$ değerlerinden büyük olduğu, $\mathrm{MSV}<\mathrm{AVE}$ ve $\mathrm{ASV}<\mathrm{MSV}$ koşullarının sağlandığı görülmektedir.

RASÇÖ'deki maddelerin ölçekten alınan toplam puanı yordama gücünü ve ayırt ediciliğini ortaya koymak amacıyla madde analizi yapılmıştır. Elde edilen analiz sonuçları \%27'lik alt ve üst gruplarda karşılaştırılmıştır. Grupların madde puanları arasındaki fark incelendiğinde her bir madde için $\mathrm{t}$ değerinin manidar olduğu ve madde toplam korelasyonunun ise .36 ile .64 arasında değiştiği belirlenmiştir. Madde toplam korelasyonunun .30 üzerinde olması ve \%27’lik alt-üst gruplara ilişkin farkın manidarlı̆̆ı, madde ayırt ediciliği açısından önemlidir (Tezbaşaran, 1997; Erkuş, 2012). Elde edilen bulgular bağlamında ölçekteki maddelerinin tamamının ayırt edici olduğu ifade edilebilir.

RASÇÖ’nün güvenirliğini ortaya koymak için Cronbach alfa katsayısı ile bileşik güvenirlik katsayısı hesaplanmıştır. Ölçeğin üç alt boyutu olan psikolojik deneyimin gerçekleşmesi, daha kötü bir durumun önlenmesi ve iyileştirilmiş durum alt boyutları için hesaplanan Cronbach alfa katsayısının .89 ile .91 değerleri arasında olduğu; orijinal ölçeğin Cronbach alfa kat sayılarının ise .85 ile .89 arasında değiştiği ortaya konmuştur. Bu veriler adapte edilen ölçeğin iç tutarlık katsayılarının orijinal ölçek ile çok yakın olduğunu göstermektedir. Bileşik güvenirlik kat sayısının ise .78 ile .83 arasında olduğu görülmektedir. Fraenkel ve diğ. (2012) tarafindan da belirtildiği gibi bileşik güvenirlik katsayısı için .70 düzeyi alanyazında kabul edilebilir bir düzey olduğundan bu çalışmada elde edilen sonuçların güvenirliği sağladığı ifade edilebilir. 


\section{SONUÇ ve ÖNERILER}

Sonuç olarak; rekreasyonda algılanan sağlık ölçeğinden elde edilen geçerlik, güvenirlik ve madde analizine ilişkin bulgular, düzenli olarak fiziksel aktivite yapan bireylerde rekreasyonda algılanan sağlık çıktılarını nicel araştırma deseni ile ölçmek için geçerli ve güvenilir sonuçlar ortaya koymuştur. Bir başka ifade ile RASÇÖ'nün yeterli psikometrik özelliklere sahip bir ölçme aracı olduğu ifade edilebilir.

Bundan sonra yapılacak çalışmalarda rekreasyonda algılanan sağlık çıktıları ölçeğinin farklı̈ örneklem ve yaş grupları üzerinde (gençler, çocuklar yaşlılar, engelliler) tekrar doğrulayıcı faktör analizi ile doğrulanarak ölçeğin geçerlik ve güvenirliğini arttıracağı düşünülmektedir.

\section{KAYNAKLAR}

1. Akgül BM, Ertüzün E, Karaküçük, S. (2018). Rekreasyon fayda ölçeği: Geçerlilik ve güvenirlik çalışması. Gazi Beden Eğitimi ve Spor Bilimleri Dergisi, 23(1), 25-34.

2. Alexandris K, Kouthouris C, Funk D, Giovani C. (2009). Segmenting winter sport tourists by motivation: The case of recreational skiers. Journal of Hospitality Marketing \& Management, 18(5), 480-499.

3. Bandalos B. (1996). Confirmatory Factor Analysis (J Stevens Ed.) Applied Multivariate Statistics for the Social Sciences. s. 389-420. Mahwah, NJ: Lawrence Erlbaum.

4. Berry C, Ahl P, Hill E, Gabriele C, Resh R, Rice J, ve diğ. (2019). Examining the health outcomes of college climbers: Applying the perceived health outcomes of recreation scale. Journal of Outdoor Recreation, Education, and Leadership 11(3), 258-261.

5. Brown P. (2016). The benefits of leisure and recreation. Journal of Park and Recreation Administration, 34(4), 103-105.

6. Budruk M, Stanis SAW. (2013). Place attachment and recreation experience preference: A further exploration of the relationship. Journal of Outdoor Recreation and Tourism 1-2, 51-61.

7. Büyüköztürk S. (2011). Sosyal Bilimler için Veri Analizi El Kitabı: Istatistik, Araștırma Deseni, SPSS Uygulamaları ve Yorum. Ankara: Pegem Akademi.

8. Büyüköztürk Ş, Çakmak EK, Akgün ÖE, Karadeniz Ş, Demirel F. (2014). Bilimsel Araştırma Yöntemleri (17. Baskı). Ankara: Pegem Akademi.

9. Chang Y-C, Yeh T-M, Pai F-Y, Huan T-P. (2018). Sport activity for health! The effects of karate participants' involvement, perceived value and leisure benefits on recommendation intention. International Journal of Environmental Research and Public Health, 15(953), 116.

10. Coşkun R, Altunıșık R, Yıldırım E, Bayraktaroğlu S. (2010). Sosyal Bilimlerde Araştırma Yöntemleri SPSS Uygulamaları. Sakarya: Sakarya Yayıncilık.

11. Comrey A, Lee H. (1992). A First Course in Factor Analysis. Hillsdale, NJ: Erlbaum.

12. Çokluk Ö, Şekercioğlu G, Büyüköztürk Ş. (2016). Sosyal Bilimler İçin Çok Değişkenli İstatistik SPSS ve LISREL Uygulamaları (4. Baskı). Ankara: Pegem Akademi.

13. Driver BL. (1998). Uses of the benefits approach to leisure. Parks\&Recreation, 33(1), 22-25.

14. Driver BL, Brown PJ, Peterson GL. (1991). Benefits of leisure. Stage College, PA: Venture Publishing.

15. Elçi G, Doğan M, Gürbüz B. (2019). Bireylerin rekreasyonda algılanan sağlık çıktıları ve yaşam doyumu düzeylerinin incelenmesi. Uluslararasi Antrenman, Egzersiz ve Spor Bilimleri Dergisi, 5(3), 93-106.

16. Erkuş A. (2012). Psikolojide Ölçme ve Ölçek Geliştirme. Ankara: Pegem Akademi Yayınları.

17. Fornell C, Larcker DF. (1981). Evaluating structural equation models with un observable variables and measurement error. Journal of Marketing Research, 18(1), 39-50.

18. Fraenkel JR, Wallen NE, Hyun HH. (2012). How to Design and Evaluate Research in Education. New York: McGraw Hill.

19. Freidt B, Hill E, Gómez E, Goldenberg M. (2010). A benefits-based study of Appalachian Trail users: Validation and application of the Benefits of Hiking Scale. Physical \& Health Education Academic Journal, 2(1), 1-22.

20. Gómez E, Hill E, Zhu X, Freidt B. (2016). Perceived health outcomes of recreation scale (PHORS): Reliability, validity and invariance, Measurement in Physical Education and Exercise Science, 20(1), 27-37.

21. Gómez E, Hill E. (2016). First landing state park: Participation patterns and perceived health outcomes of recreation at an urban-proximate park. Journal of Park and Recreation Administration, 34(1), 66-83.

22. Günbayı İ, Sorm S. (2018). Social paradigms in guiding social research design: The functional, interpretive, radical humanist and radical structural paradigms. International Journal on New Trends in Education and their Implications, 9(2), 57-76.

23. Hambleton RK, Patsula L. (1993). Increasing the validity of adapted tests: Myths to be avoided and guidelines for improving test adaptation. Journal of Applied Testing Technology, 1,1-16.

24. Hill E, Goldenberg M, Freidt B. (2009). Benefits of hiking: A means-end approach on the Appalachian Trail. Journal of Unconventional Parks, Tourism \& Recreation Research, 2(1), 19-27.

25. Ho TK. (2008). A Study of Leisure Attitudes and Benefits for Senior High School Students at Pingtung City and Country in Taiwan, Unpublished Doctoral Dissertation. United States Sports Academy. Daphne, AL.

26. Kline RB. (2005). Principles and Practice of Structural Equation Modeling (Second Edition). NY: Guildford Publications,Inc.

27. Manfredo MJ, Driver BL, Tarrant MA. (1996). Measuring leisure motivation: A meta-analysis of the Recreation Experience Preference Scales. Journal of Leisure Research, 28(3), 188-213.

28. Moore RL, Driver BL. (2005). Introduction to outdoor recreation: Providing and managing natural resource based opportunities. State College, PA: Venture Publishing.

29. Özdamar K. (2016). Eğitim, Sağlık ve Davranış Bilimlerinde Ölçek ve Test Geliştirme Yapısal Eşitlik Modellemesi IBM SPSS, IBM SPSS AMOS ve MINITAB Uygulamal, Eskișehir: Nisan Kitabevi.

30. Ravid R. (1994). Practical Statistics for Educators. New York: University Press in America.

31. Raykov T. (1998). Coefficient alpha and composite reliability with interrelated nonhomogeneous 1tems. Applied Psychological Measurement, 22(4), 375-385. 
32. Rosenthal R, Rosnow RL. (2008). Essentials of Behavioral Research: Methods and Data Analysis (Third Edition). New York: McGrawHill.

33. Seçer İ. (2015). SPSS ve LISREL ile Pratik Veri Analizi: Analiz ve Raporlaștırma. Ankara: Anı Yayıncılık.

34. Shores K, Scott D. (2007). The relationship of individual time perspective and recreation experience preferences. Journal of Leisure Research, 39(1), 28-59.

35. Stewart WP, Cole DN. (2001) Number of encounters and experience quality in grand canyon backcountry: Consistently negative and weak relationships. Journal of Leisure Research, 33(1), 106-120.

36. Stewart WP. (1992). Influence of the onsite experience on recreation experience preference judgments. Journal of Leisure Research, 24(2), $185-198$.

37. Tabachnick B, Fidell, LS. (2007). Çok Değişkenli İstatistiklerin Kullanımı. Ankara: Nobel Akademik Yayıncılık.

38. Tezbașaran A. (1997). Likert Tipi Ölçek Hazırlama Kılavuzu. Ankara: Türk Psikologlar Derneği.

39. Weber D, Anderson D. (2010). Contact with nature: Recreation experience preferences in Australian parks. Annals of Leisure Research, 13(1-2), 46-69,

40. Yaşıı̆̆lu MM. (2017). Sosyal bilimlerde faktör analizi ve geçerlilik: Keşfedici ve doğrulayıcı faktör analizlerinin kullanılması. Istanbul Üniversitesi İsletme Fakültesi Dergisi, 46(74), 74-85. 